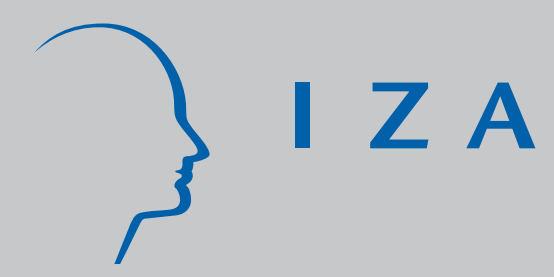

IZA DP No. 1485

The Distribution of Wages in Poland, 1992-2002

Andrew Newell

Mieczyslaw W. Socha

February 2005 


\title{
The Distribution of Wages in Poland, 1992-2002
}

\author{
Andrew Newell \\ University of Sussex \\ and IZA Bonn
Mieczyslaw W. Socha
University of Warsaw
Discussion Paper No. 1485
February 2005

\author{
IZA \\ P.O. Box 7240 \\ 53072 Bonn \\ Germany \\ Phone: +49-228-3894-0 \\ Fax: +49-228-3894-180 \\ Email: iza@iza.org
}

\begin{abstract}
Any opinions expressed here are those of the author(s) and not those of the institute. Research disseminated by IZA may include views on policy, but the institute itself takes no institutional policy positions.

The Institute for the Study of Labor (IZA) in Bonn is a local and virtual international research center and a place of communication between science, politics and business. IZA is an independent nonprofit company supported by Deutsche Post World Net. The center is associated with the University of Bonn and offers a stimulating research environment through its research networks, research support, and visitors and doctoral programs. IZA engages in (i) original and internationally competitive research in all fields of labor economics, (ii) development of policy concepts, and (iii) dissemination of research results and concepts to the interested public.
\end{abstract}

IZA Discussion Papers often represent preliminary work and are circulated to encourage discussion. Citation of such a paper should account for its provisional character. A revised version may be available directly from the author. 
IZA Discussion Paper No. 1485

February 2005

\section{ABSTRACT}

\section{The Distribution of Wages in Poland, 1992-2002*}

This paper analyses the changes in the size distribution of wages in Poland over a decade of transition. Until about 1998 there were some forces tending to increase wage inequality and other forces contracting it. The result was a relatively constant level of inequality. Privatisation was the main force tending to increase wage inequality, partly because it generated major increases in the relative wages of professional and managerial workers. We demonstrate how private firms tend to pay less at the bottom end of the wage distribution and more at the top end. The main force contracting the variance of wages was the decline, between 1992 and 1998 in labour market participation of those with low levels of education. Wage inequality seems to have increased since 2000. Suggestively, whereas privatisation has continued, the decline in participation has halted.

JEL Classification: J31, P23

Keywords: $\quad$ wages, Poland

Corresponding author:

Andrew Newell

Department of Economics

University of Sussex

Falmer, Brighton BN1 9QN

United Kingdom

Email: a.t.newell@sussex.ac.uk

* Paper prepared for Poland: How far is Warsaw from Lisbon? Growth, Employment and Living Standards in Pre-Accesion Poland, World Bank, November 2003. 


\section{Introduction}

This paper describes and analyses the changes that the transition have wrought on the distribution of wages in Poland in the decade 1992-2002. Our analysis thus complements previous work, such as Keane and Prasad (2002) who cover the early transition period up to 1996 . We find little change in overall wage inequality from 1992 to 2000, and then an increase in 2001 and 2002. The lack of change in wage inequality up to 2000 was perhaps unexpected. Our analysis, together with the work of Newell (2001a), suggests two main forces were at work, pulling the wage distribution in different directions. First, the increasing share of employment in the private sector has been a force raising wage inequality. Occupational wage premia are higher and growing further apart in Poland's private sector. Alternatively we demonstrate how the private sector tends to pay less at the low wage end of the labour market and more at the high wage end.

The main force contracting wage inequality through the 1990s was the large reduction in lower-skilled workers in employment. This came about through two mechanisms: first, young people staying on longer in education and second, the retirement of a less-educated older generation. These participation changes slowed down at the turn of the century. We speculate that the rise in wage inequality that took place in 2001 and 2002 was a result of this slowdown.

Section 2 provides and macroeconomic and institutional context for our study. Section 3 introduces our data sets and illustrates some of the trends discussed above. Section 4 reports the results of wage equation estimation, detailing initially how the responsiveness of wage to individual characteristics has changed through Poland's transition. We then report how quantile regression analysis and correcting for participation bias alter and enrich the picture of an evolving wage distribution. Section 5 concludes.

\section{Context}

\subsection{Macroeconomic Overview of the Labour Market}

From 1993 to 1998 Poland enjoyed rapid economic growth, steady employment levels and falling unemployment. During 1998 there began a macroeconomic slowdown, which was accompanied by falling employment and rising unemployment.

Four main structural changes on the demand side can be identified. Firstly, there is a large shift of labour demand away low skilled toward high-skilled employees. In 
1992-2001 the number of employed with tertiary level of education increased by $42 \%$, while workers with primary and less education decreased by $50 \%$. The employment rate of women with the latter level of education living in urban areas dropped to $12 \%$. Previous studies on the wage distribution revealed increases in the wage premia to higher education, skilled occupations and private sector employees (for details see Rutkowski 1996, Newell 2001b, Newell and Socha, 1998 and 2002).

Secondly, due fundamentally to the industrial bias of the communist system, we are observing large changes in the industrial structure of employment. LFS data show that since 1994 employment in agriculture, hunting and forestry fell by $21 \%{ }^{1}$, in mining the fall was 45\%, and in manufacturing the fall is about 12\% since 1992 . Employment in real estate and business activities increased by $166 \%$, in hotels and restaurant by $63 \%$, and in trade by $12 \%$. However since 1998 there has been a reversal of the trend with respect to rural activities and the share of agriculture, forestry and hunting in total employment increased to $20 \%$.

Thirdly, the driving force of the job creation is development of the private sector. The process of privatisation has slowed down recently, but in 2002 the share of private sector in total employment was $73 \%,{ }^{2}$ in industrial output $75 \%$, in investment $72 \%$, in exports $88 \%$ and imports $92 \%$. The private sector is dominated by small and medium size businesses ${ }^{3}$. Through the 1990s it also attracted greater proportions of, young, male and less educated workers than the public sector (Socha and Weisberg 2002). Between 1992 and 2002, the public sector lost 3.1 million workers (41\%), while employment in the private sector increased by $25 \%$.

Fourthly, there is evidence of growing importance of atypical forms of employment. The share of part-time workers is very stable at the level of $10 \%$, however the share of temporary paid workers in the total number of paid employment increased between 1992 and 2001 from 2.9\% to 12.7\%. This may be a response to increased levels of statutory employment protection. Also, the Central Statistical Office estimates of employment in the shadow economy suggest an increase from 805 thousands in 1995 to 895 thousands in 2001.

\footnotetext{
${ }^{1}$ Data for private agriculture estimated from other sources show different trend i.e. increase in the number of employed in agriculture, forestry and hunting by $6.2 \%$ with the share in total employment of $29,2 \%$.

2 including private farmers.

${ }^{3}$ The number of individual, non-incorporated businesses increased since $1992 / 3$ by $77 \%$ and in 2001 exceeded 2.66 millions establishments.
} 


\subsection{Changes in labour institutions}

Despite many attempts, structural reform of the labour market has not been completed (for details see Kwiatkowski et al, 2001). Instead, a system characterised by high levels of labour taxation, relatively generous welfare assistance and employment protection still exists.

2.2.1 Wage taxation. Compared to other transitional and OECD countries Poland has one of the highest payroll taxes (48\%) with total tax rate (income and consumption taxes included) about $80 \%$ (Riboud et al, 2002) ${ }^{4}$. To illustrate the scale of taxation, employer's contributions calculated as a percentage of gross wage in Poland are the second highest in the OECD, after the Netherlands (OECD 2001, chart 2 p. 105).

The major change in the system of labour taxation is linked to the social security and health care systems reforms of 1999. The social insurance reform introduced a division between employers' and employees' contributions. The employer's obligatory social contribution is $20.43 \%$ of gross wages. This includes social security contribution $-17.9 \%(9.76 \%$ for pension, $6.5 \%$ for disability and $2.45 \%$ for industrial injures insurance), $2.45 \%$ contribution to Labour Fund and $0.08 \%$ contribution to Benefits Guarantee Fund. The employee pays $18.71 \%$ of gross wages in form of pension insurance $(9.76 \%)$, disability insurance $(6,5 \%)$ and sickness insurance $(1.62 \%)$. The contribution to health insurance amounts to $7.75 \%$ of individual income.

2.2.2 the wage bargaining system. After restrictive anti-inflation wage taxes were abolished in 1995, the wage bargaining system has been organized through the Tripartite Commission. Wage negotiations between employers and workers can take place at the industry and the firm level. Local governments, employer or trade unions organizations are not involved in wage bargaining. Since the collective agreement can only be signed only in the enterprises with trade unions this form of industrial relations regulates the wages in state enterprises (or recently privatised large firms) and in the public non-profit entities. There are no reliable data on unionisation, however, according to Riboud et. al. (2002) Poland has the lowest union density of the accession countries $-33.8 \%$ of salaried employees (compared to $39.6 \%$ in OECD countries and $44.4 \%$ in EU countries). In the private sector, populated by small and

\footnotetext{
${ }^{4}$ Carey and Tchilinguirian (2000) estimated the average effective tax rate for labour in the period 19911995 as $42.06 \%$.
} 
medium size companies without the trade unions, wages are set by employers. There are also a few supra-enterprise agreements. The Ministry of Labour, the unions, and employers' organizations negotiate an annual wage increase in public sector and revise national minimum wage.

There are two main problems with the present wage bargaining system. First, there are large number of trade unions and employers' organizations within the enterprise and at the national level. This (a) makes it difficult to establish a clear representation of the workers and employers interests and (b) impedes co-ordination during wage bargaining. Riboud et. al (op. cit.) construct a 3-point scale for the degree of union and employer co-ordination. For Poland union co-ordination is estimated at 2 and among employers at 1 point. Second, due to the political rivalry between competing union confederations and the low level of confidence between the social partners, the credibility of the Tripartite Commission is very low. Attempts to implement the Social Pact Agreement of the government with the employers and trade unions have failed so far. Even agreements about the change in the average wages in public sector have not been reached in all years, and have sometimes had to be settled by government decree.

2.2.3 Minimum wage. The minimum wage is based on monthly remuneration and covers all sectors and types of workers. It has been revised 3-5 times a year in line with the inflation. The ratio of the minimum wage to the average wage slightly decreased during recent years from 40 to $37 \%$.

\section{PLFS Data}

Table 1 gives some wage inequality statistics from twelve rounds of the Polish Labour Force Survey (PLFS) covering the last decade. We employ these twelve rounds throughout this and the next section. There was little change in wage inequality through the 1990s. It does seem, however, that there was a moderate increase in wage inequality after 2000. For instance, the 90/10 decile ratio moves little until it jumps in the spring of 2001; thereafter it stays high. Similarly the Gini coefficient and the coefficient of variation rise (respectively from about $24 \%$ to about $26 \%$ and from about $6 \%$ to about $7 \%$ ) at the beginning of 2001 .

What caused this increase in wage inequality? A detailed look at the wages in the surveys shows that the increased inequality derives mostly from a moderate increase of the numbers of workers with low wages. We already mentioned there has been a 
drop in the minimum wage to average wage ratio in the last few years, and this might be one cause of the increase in inequality. Other possible causes include the rise of temporary contracts and also the rise in the share of employment in small firms. In our regression work below we show that as the variance of wages increases in the later rounds of the survey, so does the coefficient of determination $\left(\mathrm{R}^{2}\right)$, so rising inequality is not due to rising variance of unobservable characteristics.

Table 2 gives summary statistics on the population of working age the PLFS. Some clear trends emerge. There is a steady but inevitably slow increase in education levels. Secondly, there is a fall in participation. By adding the unemployed and employed proportions we can see there has been a significant reduction in the overall participation rate among PLFS respondents, from around $70 \%$ in the first half of the 1990s to between $66 \%$ and $67 \%$ since 1998 . This fall partly reflects the greater time spent in education by younger people, but also reflects earlier retirement.

Thirdly, there are falls in the proportions of heads of household and married people in the survey. Both these phenomena are likely to be due in part to the longer time young people are spending in education. Lastly two demographic effects are clear. First, the post-World War Two baby boomers pass from around 40 years old in 1992 to around 50 years old in 2002. Secondly the early 1980 s baby boomers become of working age.

Table 3 gives descriptive statistics of the samples of employees in the twelve rounds of the PLFS that we use for wage equation estimation. Starting at the top of the table and moving down, there are a number of trends that deserve mention. The share of women among employees has risen while, following the population trend, the share of married people in employment has fallen. The proportion of employees with more advanced education has increased rapidly; more than in the population of working age in general. By industry, mining has contracted and other manualintensive industries such as manufacturing and the power utilities have mildly falling shares. The share of workers in construction has followed a cyclical path: booming in the late 1990s and falling after 1999. The growth sectors are trade and repair and financial services.

The private sector has grown in importance. There is a related decline in the proportion of workers employed in large firms. Among occupations, the share of skilled manuals has declined, while the share of sales workers has increased; otherwise the changes are relatively small. Average potential experience increases as 
the post-war baby-boomers become older. Here and throughout potential experience is measured as equal to age -7 -years in education. On the other hand job tenures decline; more workers report relatively short job durations.

\section{Wage equation estimation}

\subsection{The evolution of pay determination over the transition period.}

Tables 4 and 5 report wage equations for the private sector and public sectors respectively. We employ twelve rounds of the PLFS, covering the nine years 19942002 inclusive in order to search for effects that are shifting over time. We estimate by Ordinary Least Squares. In section 4.3 we investigate whether quantile regression offer more subtle insights. In section 4.4 we attempt to control for the various selection biases.

Starting at the top of the list of variables, we see that the ceteris paribus gender wage gap is slightly smaller in the private sector and it narrowed sharply in both sectors after 2000. The wage return to heads of households shows a small but steady increase over time. Being a head of household often gives a positive wage return in studies like this. Most researchers rationalise the result by arguing that taking domestic responsibility reflects, or is thought by employers to reflect, an ability that enhances workplace productivity. This must be right, so any increase in the wage return might reflect the reduction in the supply of household heads noted in section 3.

The next three results suggest the private sector exhibits greater and faster rising ceteris paribus wage dispersion than the public sector. Firstly, there are large increases in the returns to all forms of post-primary education in the private sector. In the public sector, there are some increases, but they are much smaller.

Second, the positive relationship between firm size and wages is consistently more pronounced in the private sector. Additionally there appear to be increasing wage premia to skilled white-collar occupations, especially professional, managerial and technical workers. These premia are larger in the private sector than in the public sector throughout the period.

One factor that reverses this tendency for inequality to be higher in the private sector is that wage returns to potential experience are higher in the public sector, probably reflecting a greater prevalence of seniority pay scales ${ }^{5}$. However, the returns

\footnotetext{
${ }^{5}$ See section 5.2 below for more on this issue.
} 
to longer tenures in the private sector grow over the period. It is tempting to hypothesise that of those who started work after 1990 are beginning to be rewarded for loyalty.

Lastly, the impact of local unemployment on wages, the Blanchflower-Oswald wage curve effect, appears only to impact reliably in private sector wages. This result may reflect the greater importance of nationally negotiated pay rates in the public sector. Our two regional variables are the proportion urbanised, which varies from roughly 40 to 70 percent in 2002 and voivodship unemployment rate, which has a range of 14 percentage points in 2002. Taking the results from the final column of table 4, this means that the urbanisation effect on wages is at most 20 percent, while the difference in ceteris paribus wages between the lowest and the highest unemployment regions is approximately 15 percent $^{6}$.

\subsection{Quantile regression analysis.}

In Table 6 we investigate if these estimated effects vary across the wage spectrum, by estimating quantile regressions ${ }^{7}$ for the spring 2002 data set. Estimates of the LAD estimator at the $10^{\text {th }}, 25^{\text {th }}, 50^{\text {th }}, 75^{\text {th }}$ and $90^{\text {th }}$ quantiles are given in the first five columns, with OLS estimates given in the sixth column, for reference. The main results are as follows. The female wage disadvantage widens as we moving up the wage distribution. This result is familiar in transition countries; see for instance Newell and Reilly (2001). Secondly, the returns to university, post-secondary and vocational-secondary levels of education rise as we move up through the wage distribution. Thirdly the returns to working in the private sector swing from significantly negative at the bottom end of the wage distribution to significantly positive at the top end. Thus, as promised above, the private sector seems to generate greater ceteris paribus wage inequality. The returns to white collar occupations all increase across the wage spectrum as do the returns to semi-skilled work. Lastly, the returns to long experience (over 20 years) are larger at the high end of the wage spectrum. Thus, in summary, many wage determinants have larger proportional impacts on wages in the upper parts of the wage distribution.

\footnotetext{
${ }^{6}$ In a fuller version of this paper we disaggregate by gender. The main result is that in the public sector the pay of women is determined differntly to other groups, with a higher return to potential experience and a lower return to tenure.

${ }^{7}$ See Koenker and Hallock (2001) for an excellent introduction to quantile regression.
} 


\subsection{Controlling for participation bias}

In table 7 we report wage equation estimates where we have attempted to control for biases. There are several possible sources of bias. First, participation in the labour market depends importantly upon personal, household and regional characteristics, so the sample of participants is not an unbiased sample from the population. Secondly, only a fraction of participants are wage-earning employees, the others being: the unemployed, the self-employed and unpaid family workers. None of these groups report wages and neither is an unbiased selection from participants, nor from the population of working age. For instance, unemployment is always more concentrated among lower skilled workers and in the PLFS data, the self-employed and unpaid family workers are predominantly own-account farmers and their families.

There is a third potential bias due to the fact that not all employees reveal their earnings to the PLFS interviewers. In particular, white-collar workers, such as managers and clerical workers, are significantly less likely to report wages.

In principle, these three sources of bias that we might call the participation, labour force status and non-reporting biases could be dealt with separately if suitable identifying variables were available. We only have one identifying variable, see below, so we collapse the three steps into a single step and model what makes someone report their wage, as distinct from being a non-reporter. We estimate these joint participation and wage equation systems for the first two years in our sample, 1994 and 1995 and for the last two rounds of our sample, Autumn 2001 and Spring 2002 using Heckman's (1976) full maximum likelihood estimation procedure. We model participation as depending on individual characteristics, such as education, age, gender, household and marital status as well as two potentially relevant regional characteristics, the degree of urbanisation and the unemployment rate.

In the latter two rounds of the survey, we have a variable that helps identify employees who do not report wages. This variable stems from a revision in the design of the question about firm size. In later rounds of the survey, the respondent is allowed to record an uncertain response, such as 'don't know'. In earlier rounds only definite answers were allowed. We create an indicator variable called vague that takes the value 1 when a respondent is uncertain about firm size, and zero otherwise. Our hypothesis is that if a respondent is uncertain about the size of the firm, they also may not recall their wage, either out of genuine ignorance or because of an unwillingness fully to engage with the survey. 
The specifications vary in two other important ways between the two mid-1990s samples and the more recent samples. First, in the later surveys the questionnaire made the distinction between actual hours worked and normal hours. Experimentation revealed that monthly wages are much more strongly associated with normal hours than with actual hours. As a consequence, where we have normal hours, we use them. Secondly, the later questionnaires also introduced a question on apprenticeship. The response to this question is added to specifications where it is available.

The results are given in Table 7 . The estimated wage equation coefficients are in general very similar to those found in Tables 4 and 5 . There are differences, however. Most notably, the broad and large upward trend in most of the education coefficients visible in tables 4 and 5 is more-or-less absent here. The education coefficients estimated for 1994 and 1995 using the Heckman procedure are very close to those estimated by OLS. For the Autumn 2001 and Spring 2002 data sets though, these education coefficients are uniformly lower than those obtained by OLS. The result is there appears no change over time in these education effects. This is not true for any of the other coefficients in Table 7. Other than the education coefficients, the Heckman procedure generates a reassuringly similar picture to OLS. Experimentation with the hours and apprenticeship variables revealed that these specification changes played no role in changing the education coefficients.

What causes the difference between the Heckman and OLS estimated education coefficients in the 2001 and 2002 samples? The standard answer would involve returning to basic theory in labour supply. We know that better educated workers are more likely to participate. In the jargon, this means their market wages are more likely to be above their reservation wages. We also know, from the quantile regression analysis, the wage return to education is higher at higher wages. So, it is likely that non-participants experience, on average, low wage returns to education. Thus controlling for the exclusion should lead to higher estimated wage returns to education. However, we find the opposite; controlling for participation seems to lower the return to education.

The reason for this seems to be a large shift in the propensity to reveal wages especially among graduates. In the November 1994 survey 90 percent of employee respondents supplied an estimate of their monthly earnings. The proportion was a little lower among graduates, at 87 percent. In the Spring 2002 Survey, only 73 
percent of employees supplied wage information, and only 63 percent of graduates responded. So, there has been marked reduction in the amount of responses to wage questions. It is not clear why this has happened. It is not simply the result of privatisation. Private sector workers are more reluctant to reveal wages, but this only accounts for a small fraction of the drop in wage responses.

If the probability of refusing to estimate wages is inversely related to unmeasured productivity characteristics, which seems likely given the results, then the bias in this shift in the propensity to report wages accounts for the lower returns to education in the Heckman-corrected wage equation estimates.

This correction does not apply in the 1994 and 1995 samples for two reasons. First, there is much less of a bias in the reporting of wages in the earlier samples. Second, recall that since the early 1990s there has been a large fall in participation in paid employment by workers with primary or lower education, so the potential for bias is much greater now than it was. For instance, in 1994 the employee to population ratio of people with primary or lower education was about $45 \%$ of all workers. By 2002 this had dropped to about 37\%, so these people are a declining fraction of the labour force. This suggests these changes in the pattern of participation might be behind these results. The message is that the rises in estimated returns to education, visible in the Tables 4 and 5, may not be robust to biases due to changes in the pattern of participation.

\subsection{What generates low pay?}

In Table 8 we report an attempt to account for the gap in wages between workers in the lowest decile of the wage distribution and workers at the mean of the wage distribution using data from 1994 and 2002. In 2002 the gap between the mean log wage and the mean log wage in the lowest decile is 0.6126 , so that workers at the mean wage earn on average about $185 \%$ of the mean wage of those in the lowest decile. Just over half of both gaps is in the residual, i.e. it is unexplained. Some researcher designate this as unobserved productivity, and surely this is partly true, but other explanations are possible. Just under a quarter of each gap (13 out of $61 \mathrm{log}$ points in 2002, 12 out of 61 points in 1994) is due to education and occupation. The final quarter of the gap is distributed among: personal characteristics (gender, marital status and status in the household), tenure and experience, and various job characteristics. The lion's share of the explained component of the wage gap is 
therefore due to educational and occupational choices. The results for the two samples are quite similar, except for the much larger concentration of temporary workers among the low paid in the 2002 sample. Note from Table 3 and from our discussion in section 2.1 that temporary workers have increased from 3 percent of the sample of wage earners in 1994 to 13 percent in 2002.

\section{Conclusions}

First, until 2001, the distribution of wages in Poland had not become decisively more unequal through the transition. Somes forces have been pushing towards greater inequality, while others have been pulling in the opposite direction. Of the former, there has been a large widening of occupational differentials. For instance the average wage mark-up of professional and managerial over manual workers has increased sine the mid-1990s by about 20 percentage points. Newell and Socha (2002) study this rise across manufacturing industries and find it strongly associated with TFP growth and also that both TFP and the white-collar premium are strongly associated with privatisation and to a lesser extent the levels of import penetration and R\&D expenditures. But even controlling for its role in widening occupational differentials, privatisation is tending to increase wage inequality. Our quantile regression analysis demonstrates how private firms tend to pay less at the bottom end of the wage distribution and higher wages at the top end.

Participation changes have pulled in the opposite direction, towards greater wage equality at least until the end of the 1990s, as Newell (2001) demonstrates. In that paper Newell shows that all of the increase in household labour income inequality 1994-1998 was due to falling participation, using a Gini decomposition given in Appendix 2 below. Over the period from 1992 to 1998, participation fell, largely due to young people staying on longer in education. Together with the retirement of an older, less well-educated generation, this has resulted in a contraction in the share of people with no more than primary education in the population of working age from 33.7 percent in 1992 to 27.6 percent in 2002. There has been a similar fall in the share of these people among employees and this reduction in the share of potentially low wage workers has probably been a contractionary force on wage inequality.

The end of the fall in participation around the turn of the century suggests a neat theory of why wage inequality increased somewhat from 2001 onwards. We have argued this fall in participation tended to reduce inequality in wages, while 
privatisation works in the opposite direction. It tempting to argue that as privatisation continued and the fall in participation ended, increased wage inequality emerged.

Rising wage inequality is a difficult phenomenon for policy makers. There is little doubt that high income inequality can lead to lower levels of social cohesion, may cause political unrest and may retard the rate of economic growth. It is also true that some policies aimed at reducing inequality, such as redistributive tax and social security systems can have similar adverse effects. The worst situation is where redistributive policies have little effect on inequality but merely reinforce the diminution of social cohesion. 


\section{References}

Carey, David and Tchilinguirian, Harry, "Average Effective Tax Rates On Capital, Labour And Consumption", OECD Economics Department Working Papers No. 258.

GUS (2002), "Labour Force Survey in Poland in the years 1992-2001”, Central Statistical Office, Warsaw.

GUS (2002), "Labour Force Survey in Poland. III Quarter 2002”, Central Statistical Office, Warsaw.

Heckman, J. (1976), “The Common Structure of Statistical Models of Truncation, Sample Selection, and Limited Dependent Variables and a Simple Estimator for Such Models", Annals of Economic and Social Measurement, 5, 1976, 475-492.

Keane, M. P. and E. Prasad (2002) "Changes in the Structure of Earnings During the Polish Transition”, IZA Discussion Paper No 496, May.

Koenker, R. and K. F. Hallock, (2001) "Quantile Regressions", Journal of Economic Perspectives, 15: 4, 143-156.

Kwiatkowski E., Socha M. W., Sztanderska U. (2001), „Labour market flexibility and employment security. Poland", ILO Employment Paper 2001/28, ILO Geneva

MLSP (2000), "Basic Statistical Data on Social Policy", Ministry of Labour and Social Policy, Warsaw November

Newell, A (2001a) "The distribution of wages in the transition countries", IZA Bonn Discussion Paper No 267, March 2001 and University of Sussex, Discussion Papers in Economics No 70, February 2001

Newell, A (2001b) "Why have a million more Polish workers become unemployed in the midst of an economic boom?" mimeo, University of Sussex, July 2001. Paper prepared for the ILO/Ministry of Labour conference on Poland's unemployment, July 2001. 
Newell, A. and B. Reilly (2001), "The gender wage gap in the transition from communism: some empirical evidence”, Economic Systems, 25, 287-304.

Newell, A and M Socha (1998) "The roles of privatisation and changes in international trade in changes in the distribution of wages in Poland 1992-1996", Economics of Transition, 6(1).

Newell, A and M. Socha, (2002) "The rising non-manual wage premium in Poland', University of Sussex Discussion Papers in Economics, No 89 October, 2002.

Newell, A and M. Socha, (2003), 'The evolution of regional unemployment in Poland', mimeo, University of Sussex, June 2003, paper prepared for the World Bank Living Standard Assessment of Poland, 2003.

OECD (2001), “Taxing wages”, OECD Paris.

Riboud M., Sainchez-Piramo C. and Silva-Jauregui C., (2002)’Does Eurosclerosis Matter? Institutional Reform and Labor Market performance in Central and Eastern European countries in the 1990s”, World Bank SP Discussion Paper No. 0202, March 2002.

Rutkowski, J. (1996), 'High Skills Pay Off: The Changing Wage Structure During the Transition in Poland', Economics of Transition, 4, pp.89-111.

Socha M. W. And Weisberg J. (2002), „Labor market transition in Poland: changes in the public and private sectors“, International Journal of Manpower, Vol. 23 No 6. 
Table 1: Monthly wage distribution 1994-2002

\begin{tabular}{l|lllll}
\hline & $\begin{array}{l}90 / 10 \\
\text { decile } \\
\text { ratio }\end{array}$ & $\begin{array}{l}90 / 50 \\
\text { decile } \\
\text { ratio }\end{array}$ & $\begin{array}{l}50 / 10 \\
\text { decile } \\
\text { ratio }\end{array}$ & Gini & $\begin{array}{l}\text { Coefficient of } \\
\text { variation of log } \\
\text { wages }\end{array}$ \\
\hline Autumn 1994 & 2.81 & 1.84 & 1.52 & 0.238 & 0.051 \\
Autumn 1995 & 2.62 & 1.81 & 1.45 & 0.236 & 0.066 \\
Autumn 1996 & 2.71 & 1.83 & 1.49 & 0.238 & 0.064 \\
Autumn 1997 & 2.62 & 1.69 & 1.55 & 0.236 & 0.062 \\
Spring 1998 & 2.58 & 1.71 & 1.63 & 0.235 & 0.061 \\
Autumn 1998 & 2.50 & 1.79 & 1.56 & 0.231 & 0.060 \\
Autumn 1999 & 2.88 & 1.87 & 1.54 & 0.238 & 0.061 \\
Spring 2000 & 2.68 & 1.76 & 1.70 & 0.240 & 0.060 \\
Autumn 2000 & 2.50 & 1.67 & 1.50 & 0.240 & 0.061 \\
Spring 2001 & 2.91 & 1.78 & 1.64 & 0.270 & 0.072 \\
Autumn 2001 & 2.76 & 1.78 & 1.55 & 0.257 & 0.070 \\
Spring 2002 & 2.86 & 1.78 & 1.61 & 0.264 & 0.072 \\
\hline
\end{tabular}


Table 2: Summary Statistics for the Population of Working Age.

\begin{tabular}{|c|c|c|c|c|c|c|c|}
\hline Proportion who are: & \multicolumn{2}{|c|}{$1992 r 41993 r 4$} & $\overline{19941}$ & 1995 & $4 \quad 1996$ & $\overline{1997}$ & $\overline{1998 r 2}$ \\
\hline Women & 0.4876 & 0.4826 & 0.4914 & 0.4946 & 0.4917 & 0.4889 & 0.4875 \\
\hline Household head & 0.3958 & 0.3779 & 0.3835 & 0.3774 & 0.3711 & 0.3697 & 0.3610 \\
\hline Married & 0.6724 & 0.6652 & 0.6675 & 0.6553 & 0.6510 & 0.6430 & 0.6296 \\
\hline Ed-University & 0.0729 & 0.0564 & 0.0729 & 0.0727 & 0.0746 & 0.0759 & 0.0760 \\
\hline Ed-Post Sec. & 0.0326 & 0.0217 & 0.0274 & 0.0279 & 0.0266 & 0.0260 & 0.0266 \\
\hline Ed-General Sec. & 0.1956 & 0.1727 & 0.1959 & 0.1998 & 0.2054 & 0.2083 & 0.2064 \\
\hline Ed-Vocational Sec. & 0.0683 & 0.0634 & 0.0699 & 0.0695 & 0.0707 & 0.0724 & 0.0745 \\
\hline Ed-Lower Vocational & 0.2941 & 0.3112 & 0.3020 & 0.3070 & 0.3088 & 0.3116 & 0.3058 \\
\hline Ed_Primary & 0.3188 & 0.3564 & 0.3179 & 0.3103 & 0.3027 & 0.2956 & 0.2831 \\
\hline Employee & 0.4365 & 0.3770 & 0.4135 & 0.4179 & 0.4243 & 0.4315 & 0.4308 \\
\hline Unemployed & 0.0920 & 0.1105 & 0.1044 & 0.1024 & 0.0892 & 0.0766 & 0.0783 \\
\hline Employed & 0.6102 & 0.6097 & 0.5861 & 0.5833 & 0.5881 & 0.5935 & 0.5903 \\
\hline Aged 15 to 20 & 0.1504 & 0.1592 & 0.1623 & 0.1660 & 0.1644 & 0.1620 & 0.1631 \\
\hline Aged 21 to 25 & 0.0971 & 0.1037 & 0.0993 & 0.1058 & 0.1115 & 0.1127 & 0.1144 \\
\hline Aged 26 to 30 & 0.1005 & .0985 & 0.0908 & 0.0900 & 0.0918 & 0.0923 & 0.0919 \\
\hline Aged 31 to 35 & 0.1250 & 0.1178 & 0.1103 & 0.1058 & 0.0987 & 0.0971 & 0.0926 \\
\hline Aged 36 to 40 & 0.1397 & 0.1318 & 0.1370 & 0.1328 & 0.1242 & 0.1208 & 0.1111 \\
\hline Aged 41 to 45 & 0.1257 & 0.1222 & 0.1318 & 0.1301 & 0.1294 & 0.1288 & 0.1346 \\
\hline Aged 46 to 50 & 0.0777 & 0.0851 & 0.0943 & 0.1040 & 0.1151 & 0.1177 & 0.1220 \\
\hline Aged 51 to 55 & 0.0799 & 0.0779 & 0.0730 & 0.0696 & 0.0687 & 0.0736 & 0.0823 \\
\hline 56 to 60 & 0.0741 & 0.0734 & 0.0721 & 0.0676 & 0.0687 & 0.0670 & 0.0633 \\
\hline Sample Size & 37486 & 66835 & 43666 & 44374 & 44631 & 44326 & 44120 \\
\hline
\end{tabular}

\begin{tabular}{l|lllllll}
\hline Proportion who are: & $1998 r 4$ & 1999 & $2000 r 2$ & $2000 r 4$ & $2001 r 2$ & $2001 r 4$ & $2002 r 2$ \\
\hline Women & 0.4891 & 0.4893 & 0.4886 & 0.4916 & 0.4897 & 0.4914 & 0.4907 \\
Household head & 0.3662 & 0.3632 & 0.3556 & 0.3577 & 0.3583 & 0.3564 & 0.3544 \\
Married & 0.6331 & 0.6299 & 0.6158 & 0.6182 & 0.6120 & 0.6130 & 0.6060 \\
Ed-University & 0.0803 & 0.0792 & 0.0798 & 0.0828 & 0.0833 & 0.0902 & 0.0883 \\
Ed-Post Sec. & 0.0255 & 0.0257 & 0.0247 & 0.0263 & 0.0290 & 0.0285 & 0.0296 \\
Ed-General Sec. & 0.2092 & 0.2170 & 0.2104 & 0.2144 & 0.2066 & 0.2103 & 0.2092 \\
Ed-Vocational Sec. & 0.0719 & 0.0774 & 0.0778 & 0.0793 & 0.0800 & 0.0815 & 0.0863 \\
Ed-Lower Vocational & 0.3136 & 0.3106 & 0.3132 & 0.3098 & 0.3137 & 0.3173 & 0.3102 \\
Ed_Primary & 0.2904 & 0.2825 & 0.2761 & 0.2873 & 0.2858 & 0.2686 & 0.2726 \\
Employee & 0.4331 & 0.3994 & 0.3918 & 0.3926 & 0.3809 & 0.3744 & 0.3649 \\
Unemployed & 0.0816 & 0.1178 & 0.1233 & 0.1194 & 0.1383 & 0.1350 & 0.1463 \\
Employed & 0.5887 & 0.5519 & 0.5452 & 0.5446 & 0.5340 & 0.5236 & 0.5154 \\
Aged 15 to 20 & 0.1666 & 0.1663 & 0.1628 & 0.1692 & 0.1565 & 0.1626 & 0.1496 \\
Aged 21 to 25 & 0.1145 & 0.1129 & 0.1167 & 0.1142 & 0.1161 & 0.1167 & 0.1201 \\
Aged 26 to30 & 0.0935 & 0.0938 & 0.0987 & 0.0945 & 0.1003 & 0.0988 & 0.1013 \\
Aged 31 to35 & 0.0933 & 0.0872 & 0.0870 & 0.0870 & 0.0863 & 0.0884 & 0.0884 \\
Aged 36 to 40 & 0.1165 & 0.1084 & 0.1010 & 0.1021 & 0.0952 & 0.0953 & 0.0882 \\
Aged 41 to 45 & 0.1297 & 0.1307 & 0.1283 & 0.1305 & 0.1240 & 0.1216 & 0.1187 \\
Aged 46 to 50 & 0.1177 & 0.1208 & 0.1264 & 0.1195 & 0.1272 & 0.1254 & 0.1287 \\
Aged 51 to 55 & 0.0785 & 0.0907 & 0.0966 & 0.0992 & 0.1093 & 0.1057 & 0.1144 \\
Aged 56 to 60 & 0.0621 & 0.0626 & 0.0568 & 0.0583 & 0.0601 & 0.0599 & 0.0655 \\
Sample Size & 43799 & 37039 & 36894 & 38398 & 37553 & 37776 & 38132 \\
\hline
\end{tabular}


Table 3: Descriptive Statistics for Employees

\begin{tabular}{|c|c|c|c|c|c|c|}
\hline Proportion who are: & $1994 r 4$ & $1995 r 4$ & $1996 r 4$ & $1997 r 4$ & $1998 r 2$ & $1998 r 4$ \\
\hline Women & 0.4664 & 0.4680 & 0.4597 & 0.4607 & 0.4589 & 0.4688 \\
\hline Household head & 0.4957 & 0.4891 & 0.4812 & 0.4743 & 0.4710 & 0.4652 \\
\hline Married & 0.7833 & 0.7727 & 0.7641 & 0.7546 & 0.7543 & 0.7489 \\
\hline Ed-University & 0.1264 & 0.1275 & 0.1293 & 0.1309 & 0.1313 & 0.1341 \\
\hline Ed-Post Sec. & 0.0472 & 0.0474 & 0.0439 & 0.0428 & 0.0424 & 0.0423 \\
\hline Ed-General Sec. & 0.2663 & 0.2679 & 0.2710 & 0.2746 & 0.2816 & 0.2790 \\
\hline Ed-Vocational Sec. & 0.0688 & 0.0640 & 0.0639 & 0.0639 & 0.0651 & 0.0623 \\
\hline Ed-Lower Vocational & 0.3491 & 0.3589 & 0.3656 & 0.3680 & 0.3672 & 0.3679 \\
\hline Ed-Primary & 0.1414 & 0.1337 & 0.1250 & 0.1191 & 0.1116 & 0.1142 \\
\hline Agriculture & 0.0351 & 0.0321 & 0.0296 & 0.0298 & 0.0319 & 0.0287 \\
\hline Mining & 0.0484 & 0.0499 & 0.0459 & 0.0393 & 0.0350 & 0.0328 \\
\hline manufacturing & 0.2914 & 0.2903 & 0.2843 & 0.2805 & 0.2822 & 0.2774 \\
\hline Utilities & 0.0256 & 0.0247 & 0.0257 & 0.0259 & 0.0242 & 0.0230 \\
\hline Construction & 0.0706 & 0.0703 & 0.0745 & 0.0778 & 0.0778 & 0.0805 \\
\hline Trade and repair & 0.1079 & 0.1175 & 0.1195 & 0.1269 & 0.1310 & 0.1404 \\
\hline Transport & 0.0699 & 0.0721 & 0.0741 & 0.0737 & 0.0771 & 0.0719 \\
\hline Finance and real estate & 0.0489 & 0.0497 & 0.0515 & 0.0556 & 0.0546 & 0.0574 \\
\hline Public services and defence & 0.3006 & 0.2920 & 0.2947 & 0.2903 & 0.2859 & 0.2876 \\
\hline Other services & 0.0017 & 0.0013 & 0.0002 & 0.0002 & 0.0002 & 0.0003 \\
\hline Hold temporary jobs & 0.0295 & 0.0285 & 0.0300 & 0.0340 & 0.0287 & 0.0357 \\
\hline Private Sector & 0.2506 & 0.2963 & 0.3386 & 0.3793 & 0.3959 & 0.4079 \\
\hline Firm size 1 to 5 & 0.0780 & 0.0836 & 0.0860 & 0.0938 & 0.0956 & 0.1029 \\
\hline Firm size 6 to 20 & 0.1746 & 0.1753 & 0.1766 & 0.1808 & 0.1856 & 0.1883 \\
\hline Firm size 21 to 50 & 0.1671 & 0.1673 & 0.1717 & 0.1681 & 0.1729 & 0.1644 \\
\hline Firm size 51 to 100 & 0.1290 & 0.1258 & 0.1293 & 0.1219 & 0.1145 & 0.1204 \\
\hline Firm Size over 100 & 0.4513 & 0.4480 & 0.4364 & 0.4064 & 0.3959 & 0.3839 \\
\hline Professional & 0.1262 & 0.1214 & 0.1193 & 0.1200 & 0.1204 & 0.1194 \\
\hline Managerial & 0.0486 & 0.0498 & 0.0445 & 0.0424 & 0.0416 & 0.0412 \\
\hline Technical & 0.1594 & 0.1531 & 0.1569 & 0.1517 & 0.1527 & 0.1517 \\
\hline Clerical & 0.0934 & 0.0976 & 0.0987 & 0.1025 & 0.1047 & 0.1035 \\
\hline Sales & 0.0811 & 0.0871 & 0.0936 & 0.0941 & 0.0968 & 0.1009 \\
\hline Farm workers & 0.100 & 0.0085 & 0.0071 & 0.0074 & 0.0095 & 0.0082 \\
\hline Skilled manual & 0.2628 & 0.2654 & 0.2659 & 0.2617 & 0.2530 & 0.2557 \\
\hline Semi-skilled manual & 0.1053 & 0.1061 & 0.1087 & 0.1142 & 0.1160 & 0.1136 \\
\hline Unskilled & 0.1133 & 0.1111 & 0.1053 & 0.1061 & 0.1054 & 0.1059 \\
\hline Has a recent spell unemployed & 0.1638 & 0.1834 & 0.1926 & 0.2136 & 0.2155 & 0.2230 \\
\hline Full-time student & 0.0012 & 0.0031 & 0.0036 & 0.0033 & 0.0033 & 0.0048 \\
\hline Under 5 years experience & 0.1171 & 0.1231 & 0.1310 & 0.1402 & 0.1283 & 0.1461 \\
\hline 5 to 10 years experience & 0.1267 & 0.1288 & 0.1330 & 0.1291 & 0.1310 & 0.1287 \\
\hline 10 to 20 years experience & 0.3255 & 0.3146 & 0.2968 & 0.2895 & 0.2742 & 0.2779 \\
\hline Over 20 years experience & 0.4307 & 0.4335 & 0.4392 & 0.4412 & 0.4664 & 0.4473 \\
\hline 1 to 5 years tenure & 0.2273 & 0.2459 & 0.2501 & 0.2621 & 0.2759 & 0.2808 \\
\hline 5 to 10 years tenure & 0.1801 & 0.1776 & 0.1785 & 0.1803 & 0.1748 & 0.1761 \\
\hline Over 10 years tenure & 0.4431 & 0.4224 & 0.4162 & 0.3986 & 0.3860 & 0.3909 \\
\hline
\end{tabular}


Table 3 continued: Descriptive Statistics for Employees

\begin{tabular}{|c|c|c|c|c|c|c|}
\hline Proportion who are: & 1999 & $2000 r 2$ & $2000 r 4$ & $2001 r 2$ & $2001 r 4$ & $2002 r 2$ \\
\hline Women & .4611 & .4679 & .4652 & .4761 & .4730 & .4844 \\
\hline Household head & .4861 & .4951 & .4900 & .4978 & .4955 & .4984 \\
\hline Married & .7537 & .7525 & .7512 & .7434 & .7457 & .7382 \\
\hline Ed-University & .1422 & .1495 & .1462 & .1513 & .1587 & .1535 \\
\hline Ed-Post Sec. & .0420 & .0402 & .0435 & .0455 & .0443 & .0508 \\
\hline Ed-General Sec. & .2894 & .2815 & .2850 & .2738 & .2732 & .2813 \\
\hline Ed-Vocational Sec. & .0723 & .0662 & .0694 & .0720 & .0697 & .0774 \\
\hline Ed-Lower Vocational & .3509 & .3595 & .3555 & .3515 & .3570 & .3368 \\
\hline Ed-Primary & .1030 & .1028 & .1004 & .1058 & .0967 & .0998 \\
\hline Agriculture & .0300 & .0274 & .0270 & .0243 & .0244 & .0272 \\
\hline Mining & .0209 & .0232 & .0229 & .0206 & .0203 & .0207 \\
\hline manufacturing & .2762 & .2739 & .2779 & .2793 & .2697 & .2669 \\
\hline Utilities & .0243 & .0253 & .0249 & .0262 & .0252 & .0229 \\
\hline Construction & .0790 & .0815 & .0782 & .0722 & .0743 & .0631 \\
\hline Trade and repair & .1344 & .1400 & .1447 & .1536 & .1538 & .1607 \\
\hline Transport & .0738 & .0712 & .0701 & .0723 & .0675 & .0705 \\
\hline Finance and real estate & .0566 & .0578 & .0603 & .0636 & .0718 & .0693 \\
\hline Public services and defence & .3045 & .2991 & .2937 & .2870 & .2919 & .2974 \\
\hline Other services & .0004 & .0006 & .0003 & .0008 & .0011 & .0013 \\
\hline Hold temporary contracts & .0360 & .0342 & .0390 & .0846 & .0820 & .1329 \\
\hline Private Sector & .4332 & .4524 & .4651 & .4959 & .5062 & .5568 \\
\hline Firm size under 10 & $.0991^{1}$ & .1452 & .1404 & $.1721^{2}$ & .1695 & .1811 \\
\hline Firm size 10 to 20 & $.1794^{1}$ & .1350 & .1488 & $.1226^{2}$ & .1215 & .1215 \\
\hline Firm size 21 to 50 & .1685 & .1649 & .1705 & $.1694^{2}$ & .1758 & .1740 \\
\hline Firm size 51 to 100 & .1248 & .1227 & .1193 & $.1416^{2}$ & .1409 & .1478 \\
\hline Firm size over 100 & .3728 & .3725 & .3559 & $.3487^{2}$ & .3377 & .3228 \\
\hline Professional & .1230 & .1275 & .1220 & .1239 & .1229 & .1188 \\
\hline Managerial & .0418 & .0408 & .0427 & .0392 & .0396 & .0379 \\
\hline Technical & .1658 & .1568 & .1586 & .1522 & .1511 & .1587 \\
\hline Clerical & .1007 & .0959 & .1026 & .0977 & .1021 & .1023 \\
\hline Sales & .0996 & .1082 & .1081 & .1174 & .1186 & .1265 \\
\hline Farm workers & .0072 & .0070 & .0072 & .0086 & .0079 & .0088 \\
\hline Skilled manual & .2371 & .2331 & .2373 & .2267 & .2266 & .2159 \\
\hline Semi-skilled manual & .1242 & .1243 & .1214 & .1186 & .1160 & .1168 \\
\hline Unskilled & .1006 & .1064 & .1000 & .1156 & .1151 & .1143 \\
\hline Has a recent spell unemployed & .2303 & .2162 & .2379 & .0500 & .0491 & .0504 \\
\hline Full-time student & .0086 & .0072 & .0087 & .0568 & .0633 & .0637 \\
\hline Under 5 years experience & .1434 & .1219 & .1363 & .1183 & .1366 & .1252 \\
\hline 5 to 10 years experience & .1256 & .1300 & .1224 & .1292 & .1247 & .1289 \\
\hline 10 to 20 years experience & .2697 & .2654 & .2725 & .2512 & .2578 & .2495 \\
\hline Over 20 years experience & .4614 & .4827 & .4688 & .5013 & .4809 & .4964 \\
\hline 1 to 5 years tenure & .2634 & .2825 & .2745 & .2953 & .2952 & .3003 \\
\hline 5 to 10 years tenure & .1703 & .1678 & .1835 & .1799 & .1940 & .1946 \\
\hline Over 10 years tenure & .4014 & .3965 & .3995 & .3825 & .3844 & .3746 \\
\hline Apprentice & & & & .0311 & .0378 & .0194 \\
\hline
\end{tabular}

Note. For 1998 the smallest firm size category is 1-5, and the next is 6-20. For 2001 and 2002 the firm size categories change as follows: under 10 becomes under $11 ; 10$ to 20 becomes 11 to $19 ; 21$ to 50 becomes 20 to 49 ; 51 to 100 becomes 50 to 100 ; over 100 is unchanged. 
Table 4: OLS modelling of $(\log )$ monthly earnings in the private sector

\begin{tabular}{|c|c|c|c|c|c|c|}
\hline & $1994 r 4$ & $1995 r 4$ & $1996 r 4$ & $1997 r 4$ & $1998 r 2$ & $1998 r 4$ \\
\hline Voman & $.155^{* *}$ & $-0.160 * *$ & $-0.139 * *$ & $-0.138 * *$ & $0.162 * *$ & -0.145 \\
\hline ousehold & $.094 * *$ & $0.078 * *$ & $0.076^{* *}$ & $0.077 * *$ & & $0.086^{* *}$ \\
\hline arried & 17 & 0.023 & $0.033 * *$ & $0.037 * *$ & 0.0 & $0.033^{\prime}$ \\
\hline d-university & $0.406^{* *}$ & $0.493 * *$ & $0.457 * *$ & $0.439 * *$ & $0.521 * *$ & $0.449 *$ \\
\hline adary & $184 * *$ & $0.176^{* *}$ & $0.194 * *$ & $0.172 * *$ & $0.213 * *$ & $0.238 * *$ \\
\hline l-gen & $108 * *$ & $0.140 * *$ & $0.114 * *$ & $0.108 * *$ & $0.140 * *$ & $0.152 * *$ \\
\hline l-voc & $138 * *$ & $0.158 * *$ & $0.134 * *$ & $0.141 * *$ & $0.177 * *$ & $0.223^{\prime}$ \\
\hline d-low & 070 ** & $0.072 * *$ & $0.060 * *$ & $0.057 * *$ & $0.066 * *$ & $0.094^{*}$ \\
\hline d-ag & -0.044 & $-0.111 * *$ & -0.068 & $-0.098 * *$ & $-0.109 * *$ & $-0.125 * *$ \\
\hline$d-m$ & -0.042 & 0.068 & 0.097 & 0.019 & 0.070 & $0.133^{*}$ \\
\hline $\mathrm{d}-\mathrm{m}$ & -0.012 & 0.012 & -0.017 & -0.029 & 0.004 & -0.018 \\
\hline$d-l$ & 0.069 & -0.041 & 0.077 & $0.092 *$ & -0.003 & 0.021 \\
\hline d & 0.029 & $0.056^{*}$ & 0.043 & $0.084 * *$ & $0.066 * *$ & $0.073^{*}$ \\
\hline$d-1$ & -0.018 & -0.009 & 0.010 & 0.003 & $0.042 *$ & 0.000 \\
\hline det $-\mathrm{t}$ & 0.062 & $0.093 * *$ & 0.049 & $0.097 * *$ & $0.126^{* *}$ & $0.067 *$ \\
\hline$d-$ & 0.048 & 0.054 & 0.017 & $0.058^{*}$ & $0.061 *$ & $0.062 *$ \\
\hline olc & $-0.087 * *$ & $-0.074 * *$ & $-0.093 *$ & $=0.087 * *$ & $-0.057 *$ & $-0.106 * *$ \\
\hline $\mathrm{rm}$ & $D_{0}{ }_{13}$ & -0.10 & -0.08 & $-0.113^{* *}$ & -0.10 & $-0.104 * *$ \\
\hline & 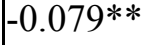 & $-0.036^{*}$ & -0.024 & $-0.028 *$ & -0.03 & $-0.060^{* *}$ \\
\hline irm & -0.01 & $0.048^{*}$ & $0.067 * *$ & $0.059 * *$ & $0.060 * *$ & 0.028 \\
\hline irm & $0.077 * *$ & $0.109 * *$ & $0.114 * *$ & $0.117 * *$ & $0.137 * *$ & $0.071 * *$ \\
\hline$c-n$ & $0.236^{* *}$ & $0.155^{* *}$ & $0.241 * *$ & $0.236^{* *}$ & $0.239 * *$ & $0.310 * *$ \\
\hline al & $0.380^{* *}$ & $0.339 * *$ & $0.378 * *$ & $0.377 * *$ & $0.391 * *$ & $0.413 * *$ \\
\hline & $0.106^{* *}$ & $0.156^{* *}$ & $0.139 * *$ & $0.149 * *$ & $0.165^{* *}$ & $0.176^{* *}$ \\
\hline & $0.055^{*}$ & $0.043 *$ & $0.059 * *$ & $0.052 * *$ & $0.066^{* *}$ & $0.084 * *$ \\
\hline & -0.046 & -0.029 & $-0.066^{* *}$ & $-0.049 * *$ & $-0.058 * *$ & $-0.055^{* *}$ \\
\hline a workers & -0.085 & 0.083 & 0.036 & -0.003 & 0.023 & 0.022 \\
\hline & 0.033 & 0.020 & $0.037 *$ & $0.035^{*}$ & $0.037 * *$ & $0.042 * *$ \\
\hline & $-0.092 * *$ & $-0.068 * *$ & $-0.067 *$ & $05 * *$ & $-0.061 *$ & $-0.072 *$ \\
\hline & -0.054 & $0.301 * *$ & 0.029 & $-0.239 * *$ & -0.265 & $-0.235 * *$ \\
\hline 5 to 10 & 0.029 & $0.066 * *$ & $0.058 * *$ & $0.047 * *$ & $0.050 * *$ & $0.081 * *$ \\
\hline & $0.069 * *$ & $0.077 * *$ & $0.045^{* *}$ & 0.023 & $0.048 * *$ & $0.061 * *$ \\
\hline Over 20 & $0.070 * *$ & $0.079 * *$ & $0.061 * *$ & 0.018 & $0.057 * *$ & $0.051 * *$ \\
\hline 1 to $5 \mathrm{y}$ & $0.052 * *$ & $0.049 * *$ & $0.034 * *$ & $0.035 * *$ & $0.039 * *$ & $0.039 * *$ \\
\hline & 0.004 & $0.042 *$ & $0.073 * *$ & $0.080 * *$ & $0.076^{* *}$ & $0.085 * *$ \\
\hline Over & 0.012 & $0.046 * *$ & $0.058 * *$ & $0.069 * *$ & $0.067 * *$ & $0.105 * *$ \\
\hline & $0.339 * *$ & $0.256 * *$ & 0.34 & $0.327 * *$ & $0.364 * *$ & $0.256^{*}$ \\
\hline & $0.003 * *$ & $0.003 * *$ & $0.002 * *$ & $0.003 * *$ & $0.002 * *$ & $0.003 *$ \\
\hline Wo & $-0.798 * *$ & $-0.338 * *$ & $-0.944 * *$ & $-0.818 * *$ & $-1.021^{*}$ & $-1.039 *$ \\
\hline Adj. R-s & 0.372 & 0.427 & 0.408 & 0.422 & 0.475 & 0.447 \\
\hline see & 0.3 & 0.3 & 0.3 & 0.391 & 0.305 & 0.312 \\
\hline $\mathrm{N}$ & 3932 & 4715 & 5380 & 6016 & 6077 & 6138 \\
\hline
\end{tabular}

Notes: $1 . *$ and $* *$ indicate significance at the 1 percent and 5 percent levels respectively.

2. The default educational group are those with no more than completed primary education. The default industry is public and other service. The default firm size is 21-50. The default occupational group skilled manual. The default level of potential experience is less than five years and the default job tenure is less than 1 year. 
Table 4: OLS modelling of $(\log )$ monthly earnings in the private sector

\begin{tabular}{|c|c|c|c|c|c|c|}
\hline & $1999 r 4$ & $2000 r 2$ & $2000 r 4$ & $2001 r 2$ & $2001 r 4$ & $2002 r 2$ \\
\hline Noman & $-0.160 * *$ & $-0.150 * *$ & -0.15 & $0.102^{*}$ & $0.131 * *$ & $-0.125^{* *}$ \\
\hline ousehold head & $097 * *$ & $0.097 * *$ & $0.102 * *$ & & $0.108 * *$ & $0.105^{* *}$ \\
\hline arried & $36 * *$ & $0.026^{*}$ & $0.056^{* *}$ & $0.049 * *$ & $0.064 * *$ & $0.053 * *$ \\
\hline d-university & ** & $0.450 * *$ & $0.447 * *$ & $0.513 * *$ & 0.51 & $0.527 * *$ \\
\hline ndary & $77 * *$ & $0.169 * *$ & $0.111 * *$ & $0.273 * *$ & $0.326^{* *}$ & $0.283 * *$ \\
\hline d-ger & $71 * *$ & $0.154 * *$ & $0.180 * *$ & $0.258 * *$ & $0.276^{* *}$ & $0.262 * *$ \\
\hline l-voc & $220 * *$ & $0.183 * *$ & $0.197 * *$ & $0.321 * *$ & 0.27 & $0.324 * *$ \\
\hline d-lov & $098^{* *}$ & $0.092 * *$ & $0.096 * *$ & $0.159 * *$ & $0.205^{* *}$ & $0.172 * *$ \\
\hline$d-a$ & -0.065 & $-0.112 * *$ & $-0.112 *$ & 0.023 & 0.035 & -0.004 \\
\hline$d-n$ & 0.099 & 0.072 & 0.082 & 0.162 & $0.196 * *$ & $0.196 * *$ \\
\hline$d-n$ & 0.031 & $-0.058 *$ & -0.026 & 0. & 0.023 & 0.031 \\
\hline$d-$ & $0.174 * *$ & 0.077 & 0.101 & 0. & $0.140 *$ & 0.111 \\
\hline & $143^{* *}$ & 0.034 & $0.071^{*}$ & 0.13 & $0.101 * *$ & $0.133^{* *}$ \\
\hline & $0.063 *$ & -0.001 & 0.021 & 0.0 & 0.0 & 0.032 \\
\hline & $136^{* *}$ & 0.060 & $0.135^{* *}$ & 0.15 & $0.161 * *$ & $0.151 * *$ \\
\hline & $0.101 * *$ & -0.001 & $0.090 * *$ & 0.1 & 0.1 & $0.087 *$ \\
\hline & $-0.106 * *$ & $-0.094 * *$ & & -0. & & $-0.086 *$ \\
\hline & 0.09 & -0.0 & -0 & -0. & -0. & $-0.078 * *$ \\
\hline & $-0.034^{*}$ & -0.024 & $-0.053 * *$ & -0.016 & -0.0 & -0.006 \\
\hline & 0.028 & $0.040^{*}$ & 0.016 & 0. & 0.0 & $0.047 *$ \\
\hline & $.100 * *$ & $0.079 * *$ & $0.068 * *$ & $0.128 * *$ & 0.1 & $0.130 * *$ \\
\hline & ** & 0.38 & $0.294 * *$ & 0.44 & 0.3 & $0.376^{* *}$ \\
\hline & & $0.478 * *$ & $0.3 \mathrm{~S}$ & 0.5 & 0.4 & $0.509 * *$ \\
\hline & & $0.246^{* *}$ & $0.201 * *$ & 0.20 & 0.2 & $0.215^{* *}$ \\
\hline & & $0.072 * *$ & $0.096^{* *}$ & 0.09 & $0.084 * *$ & $0.126^{* *}$ \\
\hline & -0.026 & $-0.072 * *$ & $-0.077 * *$ & -0.0 & ${ }^{k}-0.0$ & $-0.052 *$ \\
\hline & & 0.030 & 0.107 & & & -0.042 \\
\hline & $0.060 * *$ & 0.020 & $0.047 * *$ & $0.040^{*}$ & $0.051^{* *}$ & $0.059 * *$ \\
\hline & & $-0.081 * *$ & -0. & -0.0 & & -0.075 \\
\hline 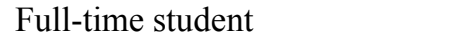 & & & & & & $-0.168 *$ \\
\hline 5 to 10 years & $0.081 * *$ & & 0.0 & $0.099 * *$ & & $0.098 * *$ \\
\hline 10 to $20 \mathrm{yec}$ & $0.070 * *$ & $0.055^{* *}$ & $0.056 * *$ & $0.110 * *$ & $0.055 * *$ & $0.092 * *$ \\
\hline Over 20 year e & $0.063 * *$ & $0.049 * *$ & 0.032 & $0.072 * *$ & 0.020 & $0.052^{*}$ \\
\hline 1 to 5 years tenure & $0.039 * *$ & $0.078 * *$ & $0.063 * *$ & 0.027 & $0.049 * *$ & $0.040^{*}$ \\
\hline 5 to 10 yea & $0.103 * *$ & $0.102 * *$ & $0.088 * *$ & $0.074 * *$ & $0.097 * *$ & $0.099 * *$ \\
\hline Over & $0.097 * *$ & $0.105 * *$ & $0.101 * *$ & $0.096 * *$ & $0.121 * *$ & $0.119 * *$ \\
\hline $\log$ & $0.274 * *$ & $0.212 * *$ & $0.205^{* *}$ & $0.523 * *$ & $0.489 * *$ & $0.518 * *$ \\
\hline Urbar & $0.003 * *$ & $0.004 * *$ & $0.004^{* *}$ & $0.006 * *$ & $0.003 *$ & $0.005^{*}$ \\
\hline & -0.082 & $-0.789 * *$ & $-1.023 * *$ & $-1.668 *$ & ${ }^{*}-0.710^{*}$ & $-1.050 * *$ \\
\hline Ad & 0.404 & 0.446 & 0.412 & 0.478 & 0.490 & 0.485 \\
\hline see & 0.3 & 0.320 & 0. & 0 . & 0.370 & 0.375 \\
\hline $\mathrm{N}$ & 4623 & 4639 & 4834 & 5281 & 5147 & 5540 \\
\hline
\end{tabular}

Notes. $1 .{ }^{*}$ and $* *$ indicate significance at the 1 percent and 5 percent levels respectively.

2 . The default educational group are those with no more than completed primary education. The default industry is public and other service. The default firm size is 21-50. The default occupational group skilled manual. The default level of potential experience is less than five years and the default job tenure is less than 1 year.

3. For 2001 and 2002 the firm size categories change as follows: under 10 becomes under $11 ; 10$ to 20 becomes 11 to $19 ; 21$ to 50 becomes 20 to $49 ; 51$ to 100 becomes 50 to 100; over 100 is unchanged. 
Table 5: OLS modelling of $(\log )$ monthly earnings in the state sector

\begin{tabular}{|c|c|c|c|c|c|c|}
\hline & $1994 r 4$ & $1995 r 4$ & $1996 r 4$ & $1997 r 4$ & $1998 r 2$ & $1998 r 4$ \\
\hline Woman & $-0.166^{* *}$ & $-0.150 * *$ & $-0.185 * *$ & $-0.181 * *$ & $-0.173 * *$ & $*-0.173^{*}$ \\
\hline Household head & $0.070 * *$ & 935". & $0.085 * *$ & $0.075 * *$ & $0.082^{* *}$ & $0.071 *$ \\
\hline arried & $039^{* *}$ & $0.059 * *$ & $0.058 * *$ & $0.043 * *$ & $0.041 * *$ & * $0.031 * *$ \\
\hline ersity & $0.418^{* *}$ & $0.431 * *$ & $0.446 * *$ & $0.440 * *$ & $0.425 * *$ & * $0.401 * *$ \\
\hline ry & $0.176^{* *}$ & $0.201 * *$ & $0.189 * *$ & $0.178 * *$ & $0.180 * *$ & $0.146 * *$ \\
\hline$y$ & & $0.157 * *$ & $0.168 * *$ & $0.171 * *$ & $0.155 * *$ & * $0.147 * *$ \\
\hline ry & & $0.187 * *$ & $0.194 * *$ & $0.169 * *$ & $0.168 * *$ & $0.144 * *$ \\
\hline d-lo & & 0.07 & & $0.049 * *$ & & $0.043 * *$ \\
\hline$d-$ & & & & $-0.036^{*}$ & & -0.009 \\
\hline $\mathrm{u}^{-}$ & & & & & & \\
\hline 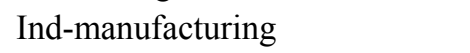 & & & & & & \\
\hline$d-$ & & & & & & \\
\hline n & & -0. & 0.0 & 0.0 & & \\
\hline & -0.0 & ${ }^{*}-0 .($ & & & & \\
\hline ad & 0.0 & & 0.0 & & & \\
\hline de & 0.08 & 0.0 & & 0.0 & & $0.0+1$ \\
\hline & -0.1 & ${ }^{*}-0.0$ & -0.1 & -0. & & \\
\hline & -0.0 & ${ }^{*}-0.0$ & -0.021 & -0.034 & -0 & \\
\hline & -0.018 & -0.019 & -0.012 & $-0.037 * *$ & & \\
\hline & 0.009 & 0.015 & 0. & -0.006 & & \\
\hline & 0.07 & 0.0 & 0.0 & 0.0 & & 0. \\
\hline & * & 0.0 & 0.0 & $3 * *$ & & \\
\hline & * & 0.2 & 0.2 & $5 *$ & & \\
\hline & 0.12 & 0.0 & 0.0 & 0.1 & & \\
\hline & $0 .($ & 0 . & 0.0 & 0.0 & $1 * *$ & \\
\hline & -0.0 & -0.0 & -0 & -0 & & \\
\hline & 0. & 35 & 43 & -0 & 43 & \\
\hline & $0.031 * *$ & 0.011 & $0.024 *$ & $0.039 * *$ & 0.020 & $0.041 * *$ \\
\hline & $-0.142 * *$ & $*-0.146 * *$ & $-0.124 * *$ & $-0.116^{* *}$ & $-0.116^{*}$ & $*-0.111 * *$ \\
\hline Ant & 0.153 & -0.053 & 0.024 & -0.040 & -0.024 & 0.018 \\
\hline & $0.060 * *$ & $=0.057 * *$ & $0.059 * *$ & $0.074 * *$ & $0.060 * *$ & \\
\hline & $0.111 * *$ & * $0.101 * *$ & $0.107 * *$ & $0.119 * *$ & $0.117 * *$ & \\
\hline 年 & $0.142 * *$ & $0.128 * *$ & $0.134^{* *}$ & $0.153 * *$ & $0.146^{* *}$ & \\
\hline to $5 \mathrm{y}$ & $0.055^{* *}$ & $0.076^{* *}$ & $0.050 * *$ & $0.057 * *$ & $0.052 * *$ & \\
\hline 5 to 10 years tenure & $0.044 * *$ & * $0.073 * *$ & $0.083 * *$ & $0.079 * *$ & $0.074 * *$ & * $0.069 * *$ \\
\hline ver 10 years tenure & $0.067 * *$ & * $0.093 * *$ & $0.095 * *$ & $0.086 * *$ & $0.090 * *$ & $0.077 * *$ \\
\hline & & & & $0.180 * *$ & & $0.232 *$ \\
\hline Urban & $0.002 * *$ & 0.0 & 0.0 & $0.002 * *$ & 0.0 & $0.002 * *$ \\
\hline Wojve & 0.046 & -0.085 & $-0.263 * *$ & $-0.400 * *$ & $-0.184^{*}$ & $=-0.414 * *$ \\
\hline di $P$ & 0.459 & 0.460 & 0.459 & 0.466 & 0.463 & 0.462 \\
\hline see & & 0.2 & 0. & 0.284 & 0.282 & 0.277 \\
\hline $\mathrm{N}$ & 11683 & 11107 & 10434 & 9782 & 9201 & 8889 \\
\hline
\end{tabular}

Notes: $1 .{ }^{*}$ and $* *$ indicate significance at the 1 percent and 5 percent levels respectively.

2. The default educational group are those with no more than completed primary education. The default industry is public and other service. The default firm size is 21-50. The default occupational group skilled manual. The default level of potential experience is less than five years and the default job tenure is less than 1 year. 
Table 5: OLS modelling of $(\log )$ monthly earnings in the state sector

\begin{tabular}{|c|c|c|c|c|c|c|}
\hline & $1999 r 4$ & $2000 r 2$ & $2000 r 4$ & $2001 r 2$ & $2001 r 4$ & $002 r^{2}$ \\
\hline & $-0.173 * *$ & & $*-0.184 * *$ & $*-0.144 * *$ & $-0.145 * *$ & 0131 \\
\hline Household head & $083 * *$ & $0.087 * *$ & $0.084 * *$ & $0.094 * *$ & $0.113 * *$ & $0.103 * *$ \\
\hline Married & $0.049 * *$ & $0.036^{* *}$ & $0.045^{* *}$ & $0.047 * *$ & $0.049 * *$ & $0.055^{* *}$ \\
\hline Ed-university & $0.435^{* *}$ & $0.414 * *$ & $0.436^{* *}$ & $0.470 * *$ & $0.424 * *$ & $0.444^{* *}$ \\
\hline Ed-pos & $0.186^{* *}$ & $0.149 * *$ & $0.138 * *$ & $0.213 * *$ & $0.179 * *$ & $0.194 * *$ \\
\hline Ed-ge & $0.154 * *$ & $0.144 * *$ & $0.147 * *$ & $0.185^{* *}$ & $0.183 * *$ & $0.185^{* *}$ \\
\hline Ed-vo & $0.195 * *$ & $0.159 * *$ & $0.203 * *$ & $0.162 * *$ & $0.244 * *$ & $0.187 * *$ \\
\hline Ed-lov & $0.046^{* *}$ & $0.063 * *$ & $0.055^{* *}$ & $0.078 * *$ & $0.096 * *$ & $0.076^{* *}$ \\
\hline Ind-a & 0.046 & -0.0 & -0.018 & 0.028 & -0.019 & $0.076^{*}$ \\
\hline Ind-n & $0.275^{* *}$ & $0.307 * *$ & $0.287 * *$ & * $0.291 * *$ & $0.279 * *$ & $0.327 * *$ \\
\hline Ind-1 & $0.062 * *$ & $0.060 * *$ & & $0.035^{*}$ & 0.025 & 0.031 \\
\hline Ind & $0.214 * *$ & $0.190 * *$ & 0.18 & $0.163 * *$ & $0.116^{* *}$ & $0.154 * *$ \\
\hline$n$ & $0.138 * *$ & 0.11 & 0.12 & $0.105 * *$ & $0.134 * *$ & 0.036 \\
\hline & 0.000 & & & 0.001 & -0.039 & 0.036 \\
\hline Ind- & $0.088^{* *}$ & $0.139 * *$ & $0.082 * *$ & $0.104 * *$ & $0.093 * *$ & $0.075 * *$ \\
\hline e & $0.126^{* *}$ & 0.12 & 0.1 & $0.105 * *$ & $0.135 * *$ & $0.070 * *$ \\
\hline & $-0.200 * *$ & & & & -0 . & * $-0.177 * *$ \\
\hline & -0.083 & -0.0 & & -0.0 & & $*-0.054 * *$ \\
\hline & -0.024 & -0.016 & -0.018 & -0.027 & $-0.045 * *$ & * $\quad-0.015$ \\
\hline & $0.038^{* *}$ & 0.022 & $0.029^{*}$ & 0.008 & 0.010 & 0.015 \\
\hline Firr & $0.069^{* *}$ & $0.076^{* *}$ & & $=0.052 * *$ & $0.043 * *$ & $0.044 * *$ \\
\hline & $*$ & 0.1 & & & 0.2 & 0.21 \\
\hline & $*$ & 0.3 & & $=0.4$ & $0.401 * *$ & 0.42 \\
\hline & $0.139 * *$ & $0.1^{\prime}$ & 0.1 & $0.130 * *$ & $0.176 * *$ & $0.158^{*}$ \\
\hline & 056 & 0.1 & 0.0 & $=0.0$ & $0.057 * *$ & 0.07 \\
\hline & & & & & & \\
\hline & & & & & -0.005 & -0.094 \\
\hline & $0.053 * *$ & 0.022 & $0.052 * *$ & 0.036 & 0.026 & $0.047 *$ \\
\hline & -0.1 & ${ }^{k}-0.1$ & $*^{*}-0.0$ & $*-0.1$ & $-0.126^{* *}$ & ${ }^{k}-0.1<-1$ \\
\hline & & & & & $-0.05^{\prime}$ & * 0.005 \\
\hline & * & & & 0.1 & $0.129 * *$ & 0.1 \\
\hline & $*$ & & & & 0.1 & $0.190 *$ \\
\hline & $*$ & & & 0.1 & $0.127 * *$ & $0.194^{*}$ \\
\hline & $*$ & & & & 0.028 & \\
\hline & $*$ & 0.0 & 0.1 & 0.1 & 0.039 & $0.070^{*}$ \\
\hline & * & 0.0 & 0.0 & 0.1 & $0.080 * *$ & 0.077 \\
\hline & * & & & $0.297 * *$ & $0.376^{* *}$ & 0.409 \\
\hline & $0.003 * *$ & 0.00 & 0.00 & $0.004 * *$ & $0.002 * *$ & $0.002 *$ \\
\hline Wo & -0.128 & $-0.304 *$ & $-0.533 * *$ & $*-0.500 * *$ & -0.202 & 0.020 \\
\hline $\mathrm{nd}$ & 439 & 0.4 & 0.449 & 0.463 & 0.479 & 0.486 \\
\hline see & 290 & 0.2 & 0.291 & 0.323 & 0.313 & 0.319 \\
\hline $\mathrm{N}$ & 6084 & 5619 & 5538 & 5372 & 5033 & 4371 \\
\hline
\end{tabular}

Notes. $1 .{ }^{*}$ and $* *$ indicate significance at the 1 percent and 5 percent levels respectively.

2 . The default educational group are those with no more than completed primary education. The default industry is public and other service. The default firm size is 21-50. The default occupational group skilled manual. The default level of potential experience is less than five years and the default job tenure is less than 1 year.

3. For 2001 and 2002 the firm size categories change as follows: under 10 becomes under $11 ; 10$ to 20 becomes 11 to $19 ; 21$ to 50 becomes 20 to 49 ; 51 to 100 becomes 50 to 100 ; over 100 is unchanged. 
Table 6: Quantile wage regressions for Spring 2002.

\begin{tabular}{|c|c|c|c|c|c|c|}
\hline & 910 & $q 25$ & $q 50$ & $q 75$ & $q 90$ & OLS \\
\hline woman & $-0.084 * *$ & $-0.112 * *$ & $-0.135^{* *}$ & $=-0.155 * *$ & $*-0.194 * *$ & $-0.127 * *$ \\
\hline Household head & $0.075 * *$ & $0.090 * *$ & $=0.102 * *$ & $=0.111 * *$ & $0.114 * *$ & $0.103 * *$ \\
\hline Married & $0.032 * *$ & $0.047 * *$ & $=0.045 * *$ & $=0.057 * *$ & $* \quad 0.057 * *$ & $0.049 * *$ \\
\hline Ed-university & $0.365 * *$ & $0.402 * *$ & $=0.417 * *$ & $=0.441 * *$ & $* \quad 0.478 * *$ & $0.470 * *$ \\
\hline Ed-post secondary & $0.183 * *$ & $0.183 * *$ & $0.156^{* *}$ & $=0.183 * *$ & $* \quad 0.231 * *$ & $0.221 * *$ \\
\hline Ed-general secondary & $0.188 * *$ & $0.169 * *$ & $=0.152 * *$ & $=0.172 * *$ & $* 0.184 * *$ & $0.211 * *$ \\
\hline Ed-vocational secondary & $0.164 * *$ & $0.183 * *$ & $0.177 * *$ & $=0.237 * *$ & $* \quad 0.255^{* *}$ & $0.254 * *$ \\
\hline Ed-lower vocational & $0.148 * *$ & $0.139 * *$ & $0.141 * *$ & $=0.179 * *$ & $* 0.195 * *$ & $0.213 * *$ \\
\hline Ind-agriculture & $-0.119 *$ & -0.006 & 0.006 & 0.024 & 0.023 & -0.006 \\
\hline Ind-mining & $0.299 * *$ & $0.293 * *$ & $=0.311 * *$ & $=0.303 * *$ & $0.244 * *$ & $0.292 * *$ \\
\hline Ind-manufacturing & 0.003 & 0.014 & 0.027 & $0.036 * *$ & 0.021 & 0.019 \\
\hline Ind -utilities & $0.146 * *$ & $0.154 * *$ & $=0.148 * *$ & $=0.167 * *$ & $0.146^{* *}$ & $0.135 * *$ \\
\hline Ind -construction & $0.085 * *$ & $0.099 * *$ & $=0.114 * *$ & $=0.101 * *$ & $0.114 * *$ & $0.097 * *$ \\
\hline Ind-trade and repair & 0.031 & 0.005 & 0.018 & 0.033 & $0.049 *$ & 0.015 \\
\hline Ind-transport & $0.088 * *$ & $0.098 * *$ & $=0.103 * *$ & $=0.111 * *$ & $0.115^{* *}$ & $0.100 * *$ \\
\hline Ind-finance and real estate & 0.025 & $0.037 *$ & $=0.085^{*} *$ & $0.086^{* *}$ & $0.097 * *$ & $0.073 * *$ \\
\hline Holds a temporary contract & $-0.125^{* *}$ & $-0.133 * *$ & $-0.118 * *$ & $-0.124 * *$ & * $-0.130 * *$ & $-0.135 * *$ \\
\hline Apprentice & $-1.246 * *$ & $-0.830 * *$ & $-0.255^{* *}$ & $=-0.229 * *$ & $*-0.258 * *$ & $-0.510 * *$ \\
\hline Private Sector & $-0.047 * *$ & $-0.029 * *$ & 0.003 & $0.032 *$ & $0.067 * *$ & 0.010 \\
\hline Firm size 1 to $10^{1}$ & $-0.080 * *$ & $-0.074 * *$ & $=-0.084 * *$ & $=-0.081 * *$ & * $-0.087 * *$ & $-0.091 * *$ \\
\hline Firm size 10 to $20^{1}$ & -0.009 & -0.006 & -0.006 & -0.018 & -0.015 & -0.010 \\
\hline Firm size 51 to $100^{1}$ & $0.050 * *$ & $0.031 *$ & $=0.026 * *$ & 0.019 & 0.015 & $0.026^{*}$ \\
\hline Firm size over $100^{1}$ & $0.042 * *$ & $0.050 * *$ & $=0.063 * *$ & $=0.085 * *$ & $* 0.106^{* *}$ & $0.071 * *$ \\
\hline Occ-professional & $0.261 * *$ & $0.260 * *$ & $=0.311 * *$ & $=0.387 * *$ & $* 0.393 * *$ & $0.333 * *$ \\
\hline Occ-managerial & $0.325 * *$ & $0.372 * *$ & $=0.456^{* *}$ & $=0.536 * *$ & $* \quad 0.654 * *$ & $0.474 * *$ \\
\hline Occ-technical & $0.072 * *$ & $0.108 * *$ & $=0.175^{* *}$ & $=0.249 * *$ & * $0.291 * *$ & $0.184 * *$ \\
\hline Occ-clerical & $0.066^{*}$ & $0.067 * *$ & $=0.077 * *$ & $=0.119 * *$ & $* 0.143 * *$ & $0.099 * *$ \\
\hline Occ-sales & $-0.050 *$ & $-0.048 * *$ & $-0.045 * *$ & -0.037 & -0.034 & $-0.044 * *$ \\
\hline Occ-farm workers & -0.027 & -0.027 & -0.027 & -0.060 & -0.051 & -0.047 \\
\hline Occ-semi-skilled & 0.033 & 0.018 & 0.020 & $0.056 * *$ & $* 0.066^{* *}$ & $0.044 * *$ \\
\hline Occ-unskilled & $-0.094 * *$ & $-0.106^{* *}$ & $-0.116^{* *}$ & $=-0.104 * *$ & * $-0.104 * *$ & $-0.091 * *$ \\
\hline Full-time student & -0.032 & $-0.038 *$ & 0.007 & 0.014 & 0.016 & -0.029 \\
\hline 5 to 10 years experience & $0.080 * *$ & $0.074 * *$ & $=0.059 * *$ & $=0.073 * *$ & 0.069 & $0.094 * *$ \\
\hline 10 to 20 year experience & $0.071 *$ & $0.065 * *$ & $=0.075 * *$ & $=0.104 * *$ & $* 0.113 * *$ & $0.112 * *$ \\
\hline Over 20 year experience & $0.059 *$ & $0.066 * *$ & $=0.083 * *$ & $=0.118 * *$ & $* 0.141 * *$ & $0.111 * *$ \\
\hline 1 to 5 years tenure & 0.024 & 0.014 & 0.025 & 0.026 & 0.015 & 0.016 \\
\hline 5 to 10 years tenure & $0.064 * *$ & $0.046^{*}$ & $=0.064 * *$ & $=0.056 * *$ & 0.040 & $0.047 * *$ \\
\hline Over 10 years tenure & $0.106 * *$ & $0.080 * *$ & $=0.082 * *$ & $=0.064 * *$ & 0.041 & $0.063 * *$ \\
\hline Log normal hours & $0.678 * *$ & $0.625 * *$ & $0.552 * *$ & $0.535 * *$ & $* 0.528 * *$ & $0.632 * *$ \\
\hline Urban wojvodship & $0.002 * *$ & $0.003 * *$ & $=0.003 * *$ & $=0.003 * *$ & $0.003 * *$ & $0.003 * *$ \\
\hline Wojvodship unemployment rate & $-0.004 * *$ & $-0.003 *$ & $-0.004 * *$ & $=-0.007 * *$ & $*-0.009 * *$ & $-0.006 * *$ \\
\hline Psuedo R-sq & 0.363 & 0.307 & 0.304 & 0.316 & 0.331 & \\
\hline Adj. R-sq & & & & & & 0.5345 \\
\hline s.e.e. & & & & & & 0.33755 \\
\hline $\mathrm{N}$ & & & & & & 10319 \\
\hline
\end{tabular}


Table 7: ML Heckman wage equation estimates, 1994. 1995, 2001, 2002

\begin{tabular}{|c|c|c|c|c|}
\hline & $\begin{array}{c}\text { November } \\
1994\end{array}$ & $\begin{array}{c}\text { November } \\
1995\end{array}$ & $\begin{array}{c}\text { Autumn } \\
2001\end{array}$ & $\begin{array}{c}\text { Spring } \\
2002 \\
\end{array}$ \\
\hline Woman & $-0.163 * *$ & $-0.156^{* *}$ & $-0.144 * *$ & $-0.130 * *$ \\
\hline Household head & $0.079 * *$ & $0.088 * *$ & $0.086 * *$ & $0.079 * *$ \\
\hline Married & $0.034 * *$ & $0.047 * *$ & $0.040 * *$ & $0.033 * *$ \\
\hline Ed-university & $0.417 * *$ & $0.437 * *$ & $0.409 * *$ & $0.396 * *$ \\
\hline Ed-post secondary & $0.178 * *$ & $0.197 * *$ & $0.191 * *$ & $0.145 * *$ \\
\hline Ed-general secondary & $0.133 * *$ & $0.151 * *$ & $0.180 * *$ & $0.157 * *$ \\
\hline Ed-vocational secondary & $0.145 * *$ & $0.178 * *$ & $0.219 * *$ & $0.216 * *$ \\
\hline Ed-lower vocational & $0.062 * *$ & $0.071 * *$ & $0.111 * *$ & $0.075 * *$ \\
\hline Ind-agriculture & $-0.077 * *$ & $-0.089 * *$ & -0.039 & -0.009 \\
\hline Ind-mining & $0.362 * *$ & $0.329 * *$ & $0.254 * *$ & $0.287 * *$ \\
\hline Ind-manufacturing & $0.016^{*}$ & $0.019^{*}$ & 0.007 & 0.018 \\
\hline Ind -utilities & $0.241 * *$ & $0.148 * *$ & $0.112 * *$ & $0.133 * *$ \\
\hline Ind -construction & $0.029 *$ & $0.035 * *$ & $0.074 * *$ & $0.096 * *$ \\
\hline Ind-trade and repair & -0.018 & -0.014 & 0.021 & 0.014 \\
\hline Ind-transport & $0.051 * *$ & $0.027 *$ & $0.096 * *$ & $0.096 * *$ \\
\hline Ind-finance and real estate & $0.086^{* *}$ & $0.053 * *$ & $0.106 * *$ & $0.072 * *$ \\
\hline Holds a temporary contract & $-0.111 * *$ & $-0.079 * *$ & $-0.156^{* *}$ & $-0.133 * *$ \\
\hline Apprentice & & & $-0.257 * *$ & $-0.504 * *$ \\
\hline Private Sector & $0.121 * *$ & $0.088 * *$ & $0.048 * *$ & 0.012 \\
\hline Firm size 1 to $5^{1}$ & $-0.097 * *$ & $-0.088 * *$ & $-0.12 * *$ & $-0.081 * *$ \\
\hline Firm size 6 to $20^{1}$ & $-0.035 * *$ & $-0.026^{* *}$ & $-0.037 * *$ & 0.001 \\
\hline Firm size 51 to $100^{1}$ & 0.001 & $0.021 *$ & $0.027 *$ & $0.036 * *$ \\
\hline Firm size over $100^{1}$ & $0.070 * *$ & $0.072 * *$ & $0.069 * *$ & $0.080 * *$ \\
\hline Occ-professional & $0.128 * *$ & $0.118 * *$ & $0.351 * *$ & $0.339 * *$ \\
\hline Occ-managerial & $0.303 * *$ & $0.309 * *$ & $0.425 * *$ & $0.489 * *$ \\
\hline Occ-technical & $0.129 * *$ & $0.118 * *$ & $0.204 * *$ & $0.190 * *$ \\
\hline Occ-clerical & $0.028^{*}$ & $0.028 * *$ & $0.081 * *$ & $0.101 * *$ \\
\hline Occ-sales & $-0.032 *$ & $-0.038 * *$ & $-0.037^{*}$ & $-0.042 * *$ \\
\hline Occ-farm workers & 0.009 & -0.000 & -0.031 & -0.051 \\
\hline Occ-semi-skilled & $0.035 * *$ & $0.020 *$ & $0.041 * *$ & $0.042 * *$ \\
\hline Occ-unskilled & $-0.126^{* *}$ & $-0.112 * *$ & $-0.093 * *$ & $-0.091 * *$ \\
\hline Full-time student & 0.059 & $0.097^{*}$ & $-0.056^{* *}$ & $-0.038 *$ \\
\hline 5 to 10 years experience & $0.048 * *$ & $0.054 * *$ & $0.070 * *$ & $0.071 * *$ \\
\hline 10 to 20 year experience & $0.092 * *$ & $0.082 * *$ & $0.055 * *$ & $0.077 * *$ \\
\hline Over 20 year experience & $0.113 * *$ & $0.101 * *$ & $0.061 * *$ & $0.078 * *$ \\
\hline 1 to 5 years tenure & $0.049 * *$ & $0.059 * *$ & -0.01 & 0.018 \\
\hline 5 to 10 years tenure & $0.031 * *$ & $0.058 * *$ & 0.016 & $0.051 * *$ \\
\hline Over 10 years tenure & $0.056 * *$ & $0.085 * *$ & $0.055 * *$ & $0.072 * *$ \\
\hline Log hours & $0.251 * *$ & $0.229 * *$ & & \\
\hline Log normal hours & & & $0.591 * *$ & $0.616^{* *}$ \\
\hline Urban wojvodship & $0.002 * *$ & $0.002 * *$ & $0.003 * *$ & $0.004 * *$ \\
\hline Wojvodship unemployment rate & $-0.196 * *$ & $-0.180 * *$ & $-0.489 * *$ & $-0.599 * *$ \\
\hline
\end{tabular}


Table 7 (continued): Heckman wage selection equations

\begin{tabular}{|c|c|c|c|c|}
\hline & $\begin{array}{c}\text { November } \\
1994\end{array}$ & $\begin{array}{c}\text { November } \\
1995\end{array}$ & $\begin{array}{c}\text { Autumn } \\
2001\end{array}$ & $\begin{array}{c}\text { Spring } \\
2002\end{array}$ \\
\hline Woman & $-0.111 * *$ & $-0.105 * *$ & -0.012 & 0.012 \\
\hline Head of Household & $0.302 * *$ & $0.294 * *$ & $0.361 * *$ & $0.391 * *$ \\
\hline Married & $0.075 * *$ & $0.059 * *$ & $0.157 * *$ & $0.162 * *$ \\
\hline Ed-university & $1.035 * *$ & $1.059 * *$ & $0.898 * *$ & $0.811 * *$ \\
\hline Ed-post secondary & $1.049 * *$ & $1.008 * *$ & $0.801 * *$ & $0.852 * *$ \\
\hline Ed-general secondary & $0.697 * *$ & $0.677 * *$ & $0.605^{* *}$ & $0.585 * *$ \\
\hline Ed-vocational secondary & $0.480 * *$ & $0.436 * *$ & $0.405 * *$ & $0.377 * *$ \\
\hline Ed-lower vocational & $0.512 * *$ & $0.527 * *$ & $0.464 * *$ & $0.387 * *$ \\
\hline Aged 21 to 25 & $0.806 * *$ & $0.805 * *$ & $0.742 * *$ & $0.824 * *$ \\
\hline Aged 26 to 30 & $1.029 * *$ & $1.042 * *$ & $0.911 * *$ & $1.035 * *$ \\
\hline Aged 31 to 35 & $0.965 * *$ & $1.008 * *$ & $0.948 * *$ & $0.987 * *$ \\
\hline Aged 36 to 40 & $1.048 * *$ & $1.068 * *$ & $0.848 * *$ & $0.978 * *$ \\
\hline Aged 41 to 45 & $1.054 * *$ & $1.045 * *$ & $0.849 * *$ & $0.957 * *$ \\
\hline Aged 46 to 50 & $0.953 * *$ & $0.938^{* *}$ & $0.763^{* *}$ & $0.867 * *$ \\
\hline Aged 51 to 55 & $0.588 * *$ & $0.612 * *$ & $0.544 * *$ & $0.668 * *$ \\
\hline Aged 56 to 60 & $-0.107 *$ & $-0.156 * *$ & $0.102 *$ & $0.187 * *$ \\
\hline Aged over 61 & $-1.308 * *$ & $-1.178 * *$ & $0.830 * *$ & $-0.790 * *$ \\
\hline Vague & & & $0.644 * *$ & $0.691 * *$ \\
\hline Urban wojvodship & $0.003 * *$ & $0.003^{* *}$ & $0.003^{* *}$ & $0.004 * *$ \\
\hline $\begin{array}{l}\text { Wojvodship } \\
\text { unemployment rate }\end{array}$ & -0.048 & -0.185 & 0.344 & -0.404 \\
\hline$\frac{1}{2} \ln \left(\frac{1+\hat{\rho}}{1-\hat{\rho}}\right)$ & 0.021 & -0.009 & $-0.208 * *$ & $-0.281 * *$ \\
\hline $\ln (\sigma)$ & $-1.170 * *$ & $-1.209 * *$ & $-1.082 * *$ & $-1.062 * *$ \\
\hline LR test $(\rho=0), \chi^{2}(1)$ & 0.23 & 0.04 & $23.16^{* *}$ & $36.68 * *$ \\
\hline Wald chi2(41) & 8529.03 & 8851.92 & 8168.56 & 8638.81 \\
\hline Log likelihood & -27253.67 & -27183 & -23283.95 & -23076.63 \\
\hline $\mathrm{N}$ & 53043 & 53761 & 47094 & 48009 \\
\hline Uncensored obs & 15615 & 15822 & 10634 & 10319 \\
\hline
\end{tabular}

Notes. 1. For 2001 and 2002 the firm size categories change as follows: under 5 becomes under $11 ; 6$ to 20 becomes 11 to $19 ; 21$ to 50 becomes 20 to $49 ; 51$ to 100 becomes 50 to 100 ; over 100 is unchanged.

2. Estimation is by Heckman's (1976) maximum likelihood method as programmed in Stata 7. 
Table 8: Accounting for the gap between wages in the lowest decile and the mean wage, full-time workers, Autumn 1994 and Spring 2002.

\begin{tabular}{l|l|l}
\hline & $\begin{array}{l}\text { Autumn } \\
1994\end{array}$ & $\begin{array}{l}\text { Spring } \\
2002\end{array}$ \\
\hline $\begin{array}{l}\text { Gap between the mean log wage and the mean log wage } \\
\text { in the lowest decile }\end{array}$ & 0.6054 & 0.6126 \\
\hline Of which: & 0.3541 & 0.3250 \\
$\quad$ unexplained & 0.2513 & 0.2876 \\
explained, of which: & 0.1213 & 0.1315 \\
$\quad$ due to education/occupation & 0.0541 & 0.0524 \\
due to personal and household factors & 0.0193 & 0.0255 \\
due to firm size & 0.0074 & 0.0256 \\
due to the share of temporary contract workers & 0.0152 & 0.0208 \\
due to tenure/experience & 0.0261 & 0.0124 \\
due to industrial differences & 0.0080 & 0.0194 \\
due to minor systematic influences &
\end{tabular}

Notes. These statistics derive from an estimated wage model specified almost exactly as in table 6. The unexplained component is the (negative) of the average residual from this regression among lowest decile workers. The explained components are calculated by multiplying mean characteristic differences by the OLS coefficients. For brevity, the regression results are not reported, but they are available from the authors on request. 
Chart 1

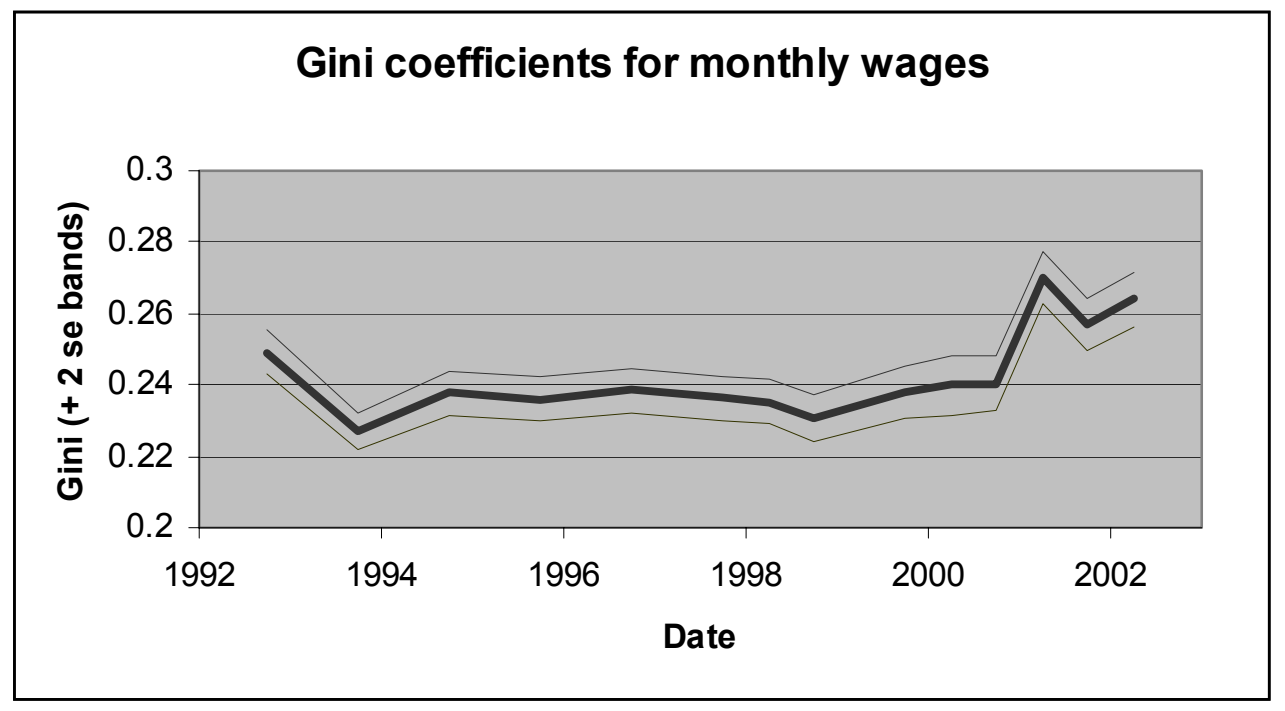


Appendix 1. Some results for data decomposed by sector and gender.

In the following tables we report coefficients estimated by OLS from separate wage equations for men and women in private and public sectors. We use specifications otherwise identical to those in Tables 4 and 5. Only a few of the results showed systematic differences by gender. These are presented below and discussed in section 4 above.

Table A1: Estimated wage impact of professional status (relative to skilled manuals)

\begin{tabular}{c|cccc}
\hline & \multicolumn{3}{|c}{ Men } & \multicolumn{2}{c}{ Women } \\
& Public sector & Private Sector & Public Sector & Private Sector \\
\hline 1994 & 0.043 & $0.228^{* *}$ & $0.158^{* *}$ & $0.265^{* *}$ \\
1995 & 0.014 & $0.17^{* *}$ & $0.138^{* *}$ & $0.175^{* *}$ \\
1996 & 0.012 & $0.185^{* *}$ & $0.139^{* *}$ & $0.342^{* *}$ \\
1997 & 0.028 & $0.194^{* *}$ & $0.180^{* *}$ & $0.318^{* *}$ \\
1998 & $0.099^{* *}$ & $0.290^{* *}$ & $0.173^{* *}$ & $0.367^{* *}$ \\
1999 & $0.076^{*}$ & $0.296^{* *}$ & $0.242^{* *}$ & $0.415^{* *}$ \\
2000 & $0.077^{*}$ & $0.243^{* *}$ & $0.218^{* *}$ & $0.384^{* *}$ \\
2001 & $0.175^{* *}$ & $0.296^{* *}$ & $0.366^{* *}$ & $0.496^{* *}$ \\
2002 & $0.141^{* *}$ & $0.368^{* *}$ & $0.228^{* *}$ & $0.451^{* *}$ \\
\hline
\end{tabular}

Table A2: Estimated wage impact of tenure over 10 years (relative to tenure of one year or less)

\begin{tabular}{c|cccc}
\hline & \multicolumn{3}{|c}{ Men } & \multicolumn{2}{c}{ Women } \\
& Public sector & Private Sector & Public Sector & Private Sector \\
\hline 1994 & $0.063^{* *}$ & -0.008 & $0.062^{* *}$ & 0.038 \\
1995 & $0.077^{* *}$ & $0.047^{*}$ & $0.070^{* *}$ & $0.051^{*}$ \\
1996 & $0.096^{* *}$ & $0.060^{* *}$ & $0.075^{* *}$ & $0.053^{*}$ \\
1997 & $0.110^{* *}$ & $0.075^{* *}$ & $0.036^{*}$ & $0.060^{* *}$ \\
1998 & $0.096^{* *}$ & $0.100^{* *}$ & $0.046^{*}$ & $0.108^{* *}$ \\
1999 & $0.072^{* *}$ & $0.092^{* *}$ & 0.014 & $0.102^{* *}$ \\
2000 & $0.124^{* *}$ & $0.096^{* *}$ & $0.047^{*}$ & $0.100^{* *}$ \\
2001 & $0.095^{* *}$ & $0.126^{* *}$ & 0.048 & $0.114^{* *}$ \\
2002 & $0.086^{*}$ & $0.103^{* *}$ & 0.051 & $0.128^{* *}$ \\
\hline
\end{tabular}

Table A3 : Estimated wage impact of experience over 20 years (relative to less than 5 years experience)

\begin{tabular}{c|cccc}
\hline & \multicolumn{3}{|c}{ Men } & \multicolumn{2}{c}{ Women } \\
& Public sector & Private Sector & Public Sector & Private Sector \\
\hline 1994 & $0.100^{* *}$ & $0.072^{* *}$ & $0.190^{* *}$ & $0.064^{*}$ \\
1995 & $0.083^{* *}$ & $0.076^{* *}$ & $0.186^{* *}$ & $0.085^{* *}$ \\
1996 & $0.053^{* *}$ & 0.040 & $0.226^{* *}$ & $0.089^{* *}$ \\
1997 & $0.123^{* *}$ & 0.031 & $0.200^{* *}$ & 0.039 \\
1998 & $0.122^{* *}$ & $0.061^{* *}$ & $0.217^{* *}$ & 0.036 \\
1999 & $0.106^{* *}$ & $0.081^{* *}$ & $0.262^{* *}$ & 0.028 \\
2000 & $0.080^{* *}$ & $0.064^{* *}$ & $0.246^{* *}$ & -0.013 \\
2001 & $0.133^{* *}$ & 0.035 & $0.148^{* *}$ & -0.000 \\
2002 & $0.201^{* *}$ & 0.052 & $0.212^{* *}$ & $0.061^{*}$ \\
\hline
\end{tabular}

Notes. Cells contain the estimated impact on log monthly wages of dummy variables indicating the relevant characteristic. As elsewhere $* *$ and $*$ indicate significance at the 1 percent and 5 percent levels. 


\section{Appendix 2. Gini coefficients}

In the text we assert that where there are households with zero earnings, changes in the Gini coefficient can be decomposed into two components. The first component is proportional to changes in Gini inequality among earners and the second component is proportional to changes in the preponderance of nonearners.

Define the overall Gini coefficient as $G_{o}$, where

$G_{o}=\frac{1}{2}-\int_{x}^{1} l(s) d s$.

Here, $x$ is the proportion of zero-income households, $s$ takes values between $x$ and unity, and $l(s)$ is the Lorenz function. The Gini coefficient of inequality among income-receiving households, $G_{w}$, is

$G_{w}=\frac{1}{2}-\int_{0}^{1} l((1-x) y+x) d y$, where $y=\frac{s}{1-x}+\frac{1}{1-x}$.

Now, $\int_{x}^{1} l(s) d s=\int_{0}^{1} l((1-x) y+x)(1-x) d y$, so

$G_{0}=\frac{x}{2}+\frac{1-x}{2} G_{w}$. Totally differentiating we have,

$d G_{o}=\frac{1-G_{w}}{2} d x+\frac{1-x}{2} d G_{w}$, as required. 